\title{
Uridine Triacetate: the First Ever Chemoprotectant for 5-Fluorouacil Toxicity
}

\author{
Krishnan $\mathrm{V}^{*}$ \\ Department of Pharmacology, Saveetha Medical College, India \\ Submission: February 01, 2017; Published: February 10, 2017
}

"Corresponding author: Krishnan V, Department of Pharmacology, Saveetha Medical College, No.162, Poonamalle High Rd, Velappanchavadi, Chennai, Tamil Nadu 600077, India, Email: doctorkrishforu@gmail.com

\begin{abstract}
Antimetabolites 5-Fluorouracil and capecitabine are used in many cancers including breast, colon, anal canal, etc. Toxicity of these agents is mild to severe and may be fatal, toxicity more common in high dose chemotherapy and patients with dihydropyromidine deficiency patients. Uridine triacetate approved as first ever chemoprotectant molecule to prevent 5-Fluorouracil and capecitabine toxicity.
\end{abstract}

Keywords: Flurouracil overdose; capecitabine adverse effects; chemoprotectant; uridine triacetate

\section{Introduction}

5 -Flurouracil (5-FU) is one the common anticancer drug belonging to antimetabolite category. Its Anatomical Therapeutic Calcification code is L01BC02 and its chemical formula is C4H3FN2O2. It is S phase specific agent, affects DNA synthesis and replication. It inhibits thymidylate synthesis enzyme and thereby conversion of deoxyuridine monophosphate to thymidine triphosphate.

Since its introduction in cancer chemotherapy, 5-FU used in various cancers. Currently it's a part of gastric cancer, breast cancer, colon cancer (FOLFOX regimen-Flurouracil, leukovorin, oxaliplatin) and (FOLIRNOX regimen-flurouracil, leukovorin, irinotecan, oxaliplatin) etc . Its congeners, floxuridine used intra-arterially in hepatic metastasis and capecitabine used in recurrent breast colon and breast cancer. 5-FU as a neoadjuvant therapy along with irradiation used in anal cancer, premalignant skin conditions and basal cell carcinoma, Adverse effects of 5-FU are considerable; they are severe gastric ulceration and fatal mucosal bleeding, severe leukopenia, hand foot syndrome, acute myocardial damage and acute cerebellar toxicity. 5-FU is one the low therapeutic index agent and requires careful precise intravenous administration. Toxic effects can be seen in normal individuals and more severe in patients with dihydropyrimidine dehydrogenase deficiency with more than eight percent mortality [1].

\section{Uridine triacetate; clinical trials and FDA approval}

This drug was granted approval by United states-Food and drug administration (US-FDA) as an orphan drug for patients with documented 5-FU toxicity or those who are exposed to high dose of 5-FU. It should be administered within 96 hours of signs and symptoms for optimum benefits. This molecule was evaluated in two trials comprising adult and pediatric patients of 135 sample sizes who were exposed to 5-FU or capecitabine and developed signs of toxicity. Success rate was more than ninety percent than the historical control where 5-FU toxicity mortality was severe and mortality rate was about $80-85$ percent [2] (Figure 1).

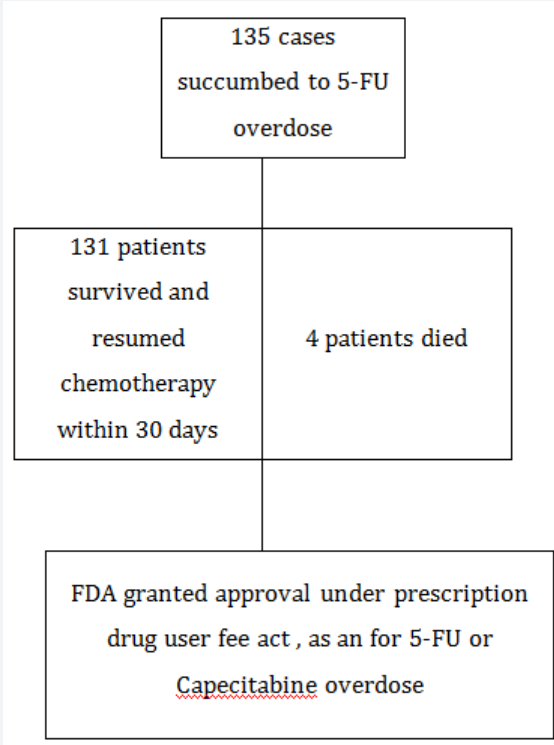

Figure1: BCR-Free survival. 


\section{Uridine Triacetate; Pharmacodynamics}

5-FU is converted in the body as as triphosphate derivative (FUTP). This derivative combines with ribonucleic acid (RNA) and form toxic intermediates which cause cell cycle arrest. Uridine from urdine triacetate is competitive to FUTP incorporation and thereby prevents the formation of toxic intermediates [3].

\section{Uridine Triacetate; Clinical Pharmacokinetics}

Its chemical formula is C15H18N209. It triacetate can be administered orally and available as oral granules in a sachet. It is s prodrug converted into active form by deacetylation and concentration maximum is attained is within two to three hours and it is also excreted faster from the body with a half of 4.5-5 hours. Dose for adults is $10 \mathrm{~g}$ every 6 hours, can be given fifteen to twenty doses and pediatric dose must be calculated based on standard formula $6 \mathrm{~g} / \mathrm{m} 2$. It does not cause renal and hepatic impairment and can be used safely in renal or hepatic insufficiency patients; however there no evidence available till date to support its use in pregnancy and lactating mother [3].

\section{UridineTriacetate; Post Marketing Status}

Post marketing surveillance did not receive any serious adverse effects uridine triacetate. The common side effects are vomiting diarrhea and mild rashes. Wa, et al. [4] a leading gastrointestinal oncologist recently said on GI cancers and drug development program at San Francisco, Uritidine triactetae is expected to reduce more than ninety five percent of deaths from 5 -Fu or capecitabine grade 3 to grade 5 toxicity. Few other reports are also encouraging the use of uridine triacetate [4-6].

\section{Conclusion}

Uridine triacetate discovery tends to ameliorate all the adverse effects of 5-FU without compromising its efficacy enables more efficient use of 5-FU with good patient compliance.

\section{References}

1. Bruce Achabner, Joesh Britino, James Cleary, Taylor Ortiz, Andrew lane, et al. Cytotoxic agents. Googman \&Gilman. The Pharmacological basics of therapeutics (12 ${ }^{\text {th }}$ edn) Mc Graw HHill, Newyork, USA, p.1677-1731.

2. FDA News Release. FDA approves first emergency treatment for overdose of certain types of chemotherapy. [Internet]. US Food and Drug Administration.

3. FDA drug label. Prescribing information of uridine triacetate [Internet]. US Food and Drug Administration.

4. Christine E, Vaudo, Brigitte Gil, Kari GaluskiCorrine Zarwan, Francis W (2016) Early-Onset 5-Fluorouracil Toxicity in a Patient Negative for Dihydropyrimidine Dehydrogenase Mutations: The Clinical Course of Reversal With Uridine Triacetate. Pharmacotherapy 36(11): e178-e182.

5. Ison G, Beaver JA, McGuinn WD, Palmby TR, Dinin J, et al. (2016) FDA Approval: Uridine Triacetate for the Treatment of Patients Following Fluorouracil or Capecitabine Overdose or Exhibiting Early-Onset Severe Toxicities Following Administration of These Drugs. Clin Cancer Res 22(18): 4545-4549.

6. Saif MW, Diasio RB (2016) Benefit of Uridine Triacetate (Vistogard) in Rescuing Severe 5-Fluorouracil Toxicity in Patients with Dihydropyrimidine Dehydrogenase (DPYD) Deficiency. Cancer Chemother Pharmacol 78(1): 151-156.

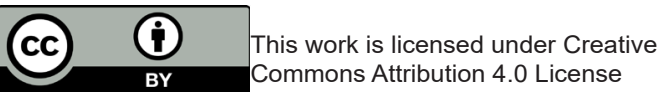

Your next submission with Juniper Publishers
will reach you the below assets
- Quality Editorial service
- Swift Peer Review
- Reprints availability
- E-prints Service
- Manuscript Podcast for convenient understanding
- Global attainment for your research
- Manuscript accessibility in different formats
( Pdf, E-pub, Full Text, Audio)
- Unceasing customer service
Track the below URL for one-step submission
https://juniperpublishers.com/online-submission.php

